\title{
Differential Regulation of Cytochrome C Release in Dexamethasone-Resistant 7TD1 Cells
}

\author{
Kalyan J. Gangavarapu ${ }^{1}$, Alok Bhushan ${ }^{1,2}$, James C. K. Lai ${ }^{1,2}$, Christopher K. Daniels ${ }^{1,{ }^{*}}$ \\ ${ }^{1}$ Department of Biomedical and Pharmaceutical Sciences, College of Pharmacy, Idaho State University, Pocatello, USA; ${ }^{2}$ ISU Bio- \\ medical Research Institute, Idaho State University, Pocatello, USA. \\ Email: *cdaniels@pharmacy.isu.edu
}

Received March 21 ${ }^{\text {st }}, 2013$; revised April 15 $5^{\text {th }}, 2013$; accepted April 23 ${ }^{\text {rd }}, 2013$

Copyright (C) 2013 Kalyan J. Gangavarapu et al. This is an open access article distributed under the Creative Commons Attribution License, which permits unrestricted use, distribution, and reproduction in any medium, provided the original work is properly cited.

\begin{abstract}
Interleukin-6 (IL6)-triggered JAK/STAT3 and PI3K/AKT signaling pathways are known to mediate cell survival, drug resistance and progression in a variety of cancer cells. Resistance to induction of apoptosis plays a critical role in the pathogenesis of numerous cancers and development of resistance to chemotherapeutic agents used in its treatment. Previous research in our laboratory employing a dexamethasone-resistant subline (7TD1-Dxm) of IL6-dependent 7TD1 cells indicated that constitutively activated STAT3 was important in control of apoptosis and targets downstream to activated STAT3 appeared to be involved in the development of resistance to dexamethasone by 7TD1 cells. We therefore investigated the hypothesis that Dxm-resistance developed by 7TD1-Dxm cells was due to resistance to induction of apoptosis mainly because of the dysregulation of the downstream targeted in JAK/STAT3 signaling pathway. Our results indicate that 7TD1-Dxm cells show resistance to Dxm-induced reduction of Bcl-2 protein and the release of cytochrome c. Thus, this study suggests that development of resistance to dexamethasone by 7TD1 cells may involve altered regulation of mitochondrial anti-apoptotic proteins.
\end{abstract}

Keywords: Interleukin-6; 7TD1 Cells; Apoptosis; Cytochrome C; Dexamethasone Resistance

\section{Introduction}

Interleukin-6 (IL6) is a pleiotropic cytokine involved in the progression of various cancers like colon, pancreatic and prostate cancers and multiple myeloma (MM) [1-7]. It is known to mediate development of drug resistance in prostate cancer and MM [4-7]. For instance, IL6 promotes cell proliferation and protects from dexamethasone (Dxm)-induced apoptosis by triggering three main signaling pathways including JAK/STAT3, PI3K/AKT, and MAPK signaling pathways [8-11]. These factors contribute to the cells' development of resistance to a variety of chemotherapeutic agents. These observations are important to our understanding of the molecular mechanisms leading to drug resistance, especially to chemotherapeutic agents like dexamethasone and may lead us to find potential targets that can induce apoptosis in Dxm-resistant cells.

The Bcl-2 family of anti-apoptotic proteins, including $\mathrm{Bcl}-2, \mathrm{Bcl}-\mathrm{X}_{\mathrm{L}}$ and $\mathrm{Mcl}-1$, are known to be over-expressed and to play an important role in cell survival and

\footnotetext{
${ }^{*}$ Corresponding author.
}

development of resistance to chemotherapeutic agents like dexamethasone [12-17]. Moreover, IL6-triggered JAK/ STAT3 signaling pathway plays a critical role in the regulation of anti-apoptotic proteins. Activation of STAT3 by phosphorylation promotes the transcriptional activation of Bcl-2 family proteins including $\mathrm{Bcl}-2, \mathrm{Bcl}-\mathrm{X}_{\mathrm{L}}$ and Mcl-1 [16,18-21].

We have developed a dexamethasone-resistant subline of IL6-dependent 7TD1 cells (7TD1-Dxm) by chronic treatment with dexamethasone. Our previous findings suggested that STAT3 constitutive activation in 7TD1 cells was important for control of apoptosis but mechanisms for dexamethasone resistance were located downstream of STAT3 activation, and may include targets like Bcl-2, Bcl- $\mathrm{X}_{\mathrm{L}}$ and Mcl-1 [22]. We therefore hypothesized that $\mathrm{Bcl}-2$ family proteins may be contributing to development of resistance to dexamethasone by 7TD1 cells. Our strategy to investigate this hypothesis was to elucidate the effect of inhibition of Bcl-2 protein on inhibition of proliferation, induction of apoptosis, release of cytochrome $\mathrm{c}$ and its consequence on the mitochondrial membrane potential (MMP). Thus, this study aimed at 
further delineating mechanisms responsible for resistance to dexamethasone in 7TD1-Dxm cells.

\section{Methods}

\subsection{Cell Culture}

7TD1 cells were grown in complete culture medium as described previously $[22,23]$. The cells were cultured with $4 \mathrm{ng} / \mathrm{ml}$ recombinant human IL6 (Upstate Biotechnology, Lake Placid, NY). Chronically treated cells (7TD1-Dxm) were continuously cultured in the presence of dexamethasone $(85 \mu \mathrm{M})$ and in the absence of IL6 over a period of three months to generate the resistant subline, 7TD1-Dxm. This subline was maintained in culture with dexamethasone $(85 \mu \mathrm{M})$ and without IL6. Dexamethasone was dissolved in ethanol at $1 \mathrm{mg} / \mathrm{ml}$ stock solution. HA-14-1 (Sigma Aldrich, St.Louis, MO) was dissolved in dimethylsulfoxide (DMSO) at a stock concentration of $50 \mathrm{mM}$. Appropriate vehicle controls were included in experiments. Cellular proliferation was monitored using the MTT assay [22,23] as described previously [24]. All experimental procedures were carried out with a prior wash-out period of $24 \mathrm{hrs}$ during which both the cell lines were incubated without IL6 or Dxm. All experiments utilized parent 7TD1 cells between passages 30 and 60 .

\subsection{Western Blotting}

As previously described [22], cells were harvested by centrifugation at $200 \times \mathrm{g}$ for 6 minutes and whole cell lysates prepared using a lysis buffer containing $20 \mathrm{mM}$ Tris- $\mathrm{HCl}$ (pH 7.6), $100 \mathrm{mM}$ sodium chloride, $2 \%$ Triton $\mathrm{X}-100,10 \mathrm{mM}$ EDTA (Ethylene diamine tetraacetic acid), $100 \mathrm{mM}$ sodium fluoride, $60 \mathrm{mM}$ sodium pyrophosphate, $0.2 \%$ sodium azide, $0.2 \mathrm{mM}$ sodium orthovanadate, $1 \mathrm{mM}$ PMSF (Phenylmethanesulfonyl fluoride), $20 \mu \mathrm{g} / \mathrm{ml}$ leupeptin, and $2 \mu \mathrm{g} / \mathrm{ml}$ aprotonin. Lysates were subsequently sonicated for 5 seconds and centrifuged at $5200 \times \mathrm{g}$ for 10 minutes; the resulting supernatant was mixed with $3 \times$ SDS loading buffer and incubated at $90^{\circ} \mathrm{C}$ for 3 minutes. The proteins were then separated on a $10 \%$ $(\mathrm{w} / \mathrm{v})$ polyacrylamide gel. Separated proteins were transferred to a PVDF membrane by electroblotting at $100 \mathrm{~V}$ for $1 \mathrm{hr}$. After transferring, the PVDF membrane was blocked in a solution containing $5 \%$ milk powder and $2.5 \%$ bovine serum albumin (BSA) in $1 \times$ Tris-buffered saline with $0.05 \%$ tween (TBST) at $4{ }^{\circ} \mathrm{C}$ for $6 \mathrm{hrs}$ and then washed with $1 \times$ Tris-buffered saline (TBS) and $1 \times$ TBST for four and three times, respectively. After washing, the membrane was probed with primary antibody for total $\mathrm{Bcl}-2$ protein and $\mathrm{Bcl}-\mathrm{X}_{\mathrm{L}}$ (1:1000 dilutions, Cell Signaling Technology, Danvers, MA) at $4^{\circ} \mathrm{C}$ overnight, followed by washing with $1 \times$ TBS and $1 \times$ TBST for four and three times, respectively. The membrane was then probed with Horse-Radish Peroxidase (HRP) labeled goat anti-rabbit IgG secondary antibody (1:2500 dilutions, KPL, Gaithersburg, MD). Blots were then processed by Pierce chemiluminiscence kit (Thermo Scientific, Rockford, IL) as recommended by the commercial vendor and autoradiographed on an X-ray film (RPI corp, Mt. Prospect, IL). Western blot analysis was carried out in triplicates.

\subsection{Detection of Apoptosis}

Apoptotic cells were quantified using the DNA fragmentation TUNEL assay (Molecular Probes, Eugene, OR). Briefly [22], 7TD1 and 7TD1-Dxm cells were subjected to various specified treatments, incubated for 48 hrs, washed with $1 \times$ PBS, fixed in a mixture of ice-cold $1 \times$ PBS: $70 \%$ ethanol, and kept at $-20^{\circ} \mathrm{C}$ for $12-18 \mathrm{hrs}$. The cells were washed with $1 \times$ PBS, stained using the APOBrdu TUNEL assay kit according to the manufacturer's protocol, and analyzed using a flow cytometer (Becton Dickinson, San Jose, CA).

\subsection{Cytochrome C Release Assay}

Cytochrome c release into cytoplasm was quantified using a cytochrome c release assay kit (Calbiochem, La Jolla, CA). Briefly, 7TD1 and 7TD1-Dxm cells were subjected to various specified treatments, incubated for $24 \mathrm{hrs}$, washed twice with $1 \times$ PBS, resuspended in $300 \mu \mathrm{l}$ permeabilization buffer and incubated on ice for $10 \mathrm{~min}$ utes. After permeabilization, the cells were fixed in $8 \%$ paraformaldehyde in PBS for a period of 20 minutes at room temperature. After fixing, the cells were washed twice in $1 \times$ wash buffer and resuspended in $250 \mu 1$ of blocking buffer and kept at room temperature for $1 \mathrm{hr}$. After incubation, $250 \mu \mathrm{l}$ of anti-cytochrome c antibody working solution was added to each sample and incubated for $1 \mathrm{hr}$ at room temperature. The cells were then washed twice with $1 \times$ wash buffer. They were then resuspended in $500 \mu 1$ of anti-IgG FITC and incubated again for $1 \mathrm{hr}$ at room temperature. They were then washed with $1 \times$ washed buffer and resuspended in $400 \mu \mathrm{l}$ of wash buffer and analyzed using flow cytometer (Becton Dickinson, San Jose, CA).

\subsection{Determination of Mitochondrial Membrane Potential (MMP)}

MMP was analyzed using two Mitotracker dyes Mitotracker red and Mitotracker green (Molecular probes, Eugene, OR). Mitotracker red binds to non-depolarized mitochondria, and Mitotracker green binds to all mitochondria. Thus, a ratio of non-depolarized to total mitochondria was calculated to estimate the MMP. Briefly, 7TD1 and 7TD1-Dxm cells were subjected to various specified treatments, and incubated for $24 \mathrm{hrs}$. At the end 
of indicated time point, Mitotracker red and Mitotracker green dyes were added for a final concentration of 250 $\mathrm{nM}$ and $150 \mathrm{nM}$, respectively. They were then incubated at $37^{\circ} \mathrm{C}$ for 30 minutes, centrifuged at $200 \times \mathrm{g}$ for 6 minutes, washed and resuspended in $1 \times$ ice cold, PBS and analyzed by flow cytometer (Becton Dickinson, San Jose, $\mathrm{CA}$ ). The ratio of mean red and green fluorescence intensities is expressed relative to the control group.

\subsection{Statistical Analysis of Data}

Statistical significance of experimental results was analyzed by univariate analysis of variance followed by Tukey's post-hoc test with a minimum significance level set at $\mathrm{P}<0.05$. In figures, individual letters identify those treatment groups where the differences are statistically significant as indicated by ANOVA (e.g., all treatment groups identified by a letter " $a$ " are statistically significantly different from those treatments identified by all other letters, "b", “c", etc.).

\section{Results}

\subsection{Proliferation of Dxm-Resistant 7TD1 Cells Was Inhibited in a Concentration-Dependent Manner upon Treatment with HA-14-1, a Bcl-2 Specific Inhibitor}

Consistent with our previous observations [22], 7TD1Dxm cells were resistant to inhibition of proliferation by dexamethasone treatment as compared to parent 7TD1 cells. To examine the role of inhibition of Bcl-2, an antiapoptotic protein, on proliferation of 7TD1-Dxm cells, we initially treated 7TD1-Dxm cells with HA-14-1, a Bcl-2 specific inhibitor. Figure 1 shows that treatment with HA-14-1 inhibited proliferation of 7TD1-Dxm cells in concentration-dependent manner with maximum inhibition observed at $20 \mu \mathrm{M}$ (a 4-fold decrease was observed).

\subsection{Treatment with HA-14-1 at a Concentration That Showed Maximum Inhibition of Proliferation Induces Apoptosis in Dxm-Resistant 7TD1 Cells}

We next examined the effect of HA-14-1 on induction of apoptosis. Figure 2 shows that treatment of both sensitive and resistant cells with $20 \mu \mathrm{M}$ HA-14-1 alone had a significant impact on induction of apoptosis (40\% - 60\% apoptotic cells were seen as compared to control) in both the lines. Addition of dexamethasone with HA-14-1 did not have further effect on induction of apoptosis as compared to treatment with HA-14-1 alone.

This finding suggests that inhibition of Bcl-2 at the concentration required for maximum inhibition of prolif-

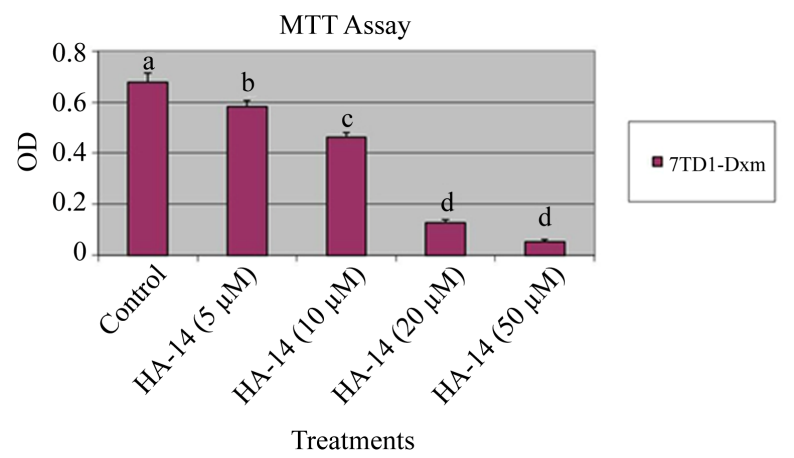

Figure 1. Treatment with HA-14-1, a Bcl-2 specific inhibitor, inhibited proliferation of 7TD1-Dxm cells in a concentration-dependent manner. 7TD1-Dxm cells were treated in the absence of interleukin-6 (4 ng/ml) or HA-14-1, a Bcl-2 inhibitor $(5,10,20$ and $50 \mu \mathrm{M})$ alone. After $72 \mathrm{hrs}$, cell proliferation was determined using the MTT assay. Values represent mean O.D. \pm S.D. for triplicate assays.

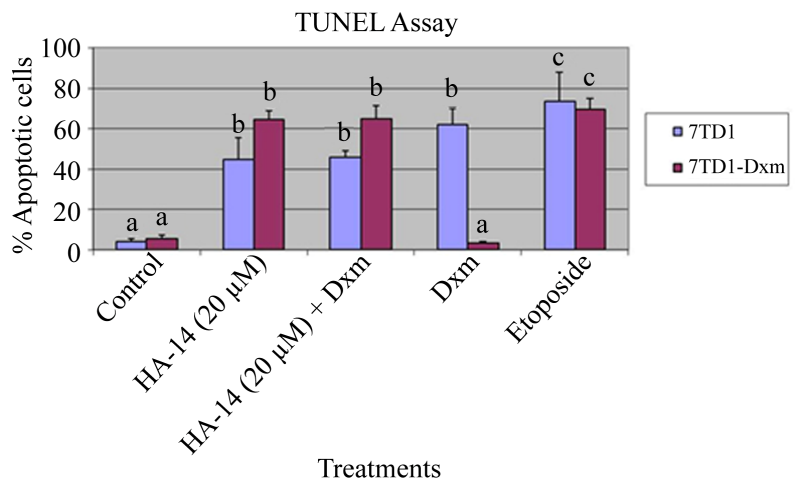

Figure 2. Treatment of 7TD1-Dxm cells with HA-14-1 induced apoptosis but did not alter resistance to dexamethasone. 7TD1-Dxm cells were treated for 48 hrs either with 20 $\mu M$ HA-14-1, alone or with $85 \mu M$ dexamethasone in the presence of $20 \mu \mathrm{M}$ HA-14-1. After 48 hrs treatment, cells were evaluated for apoptosis using the TUNEL assay and DNA fragmentation therein analyzed by flow cytometry. Values represent the average percent apoptotic cells \pm S.D. for triplicate assays. Etoposide, at $10 \mu \mathrm{M}$, was used as a positive control.

eration was sufficient to induce apoptosis but did not alter the resistance of 7TD1-Dxm cells to dexamethasone treatment.

\subsection{TD1-Dxm Cells Were Resistant to Reduction of Bcl-2 Protein Expression upon Treatment with Dexamethasone}

Since inhibition of Bcl-2 by HA-14-1 blocked proliferation and induced apoptosis in both parent 7TD1 and 7TD1-Dxm cells, we next examined Bcl- $\mathrm{X}_{\mathrm{L}}$ and $\mathrm{Bcl}-2$ protein expression. Figure 3(a) shows that treatment with AG490, a JAK inhibitor, alone at $50 \mu \mathrm{M}$ or dexamethasone alone at $85 \mu \mathrm{M}$ had an effect of reducing protein levels of Bcl-2 in parent 7TD1 cells. 7TD1-Dxm 


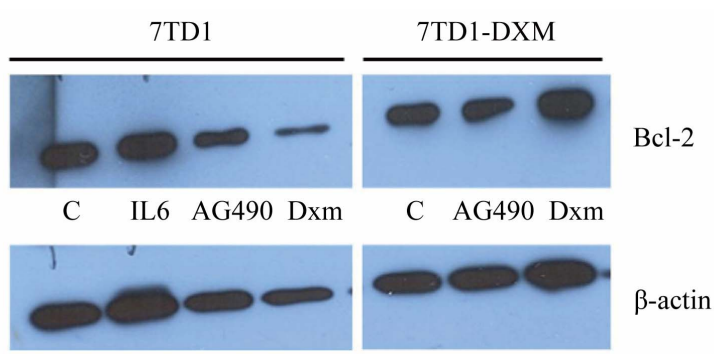

(a)

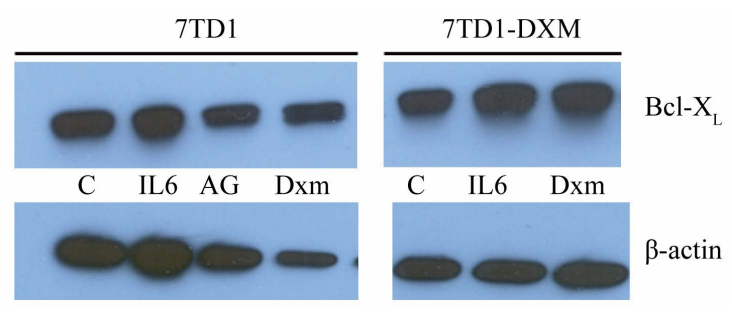

(b)

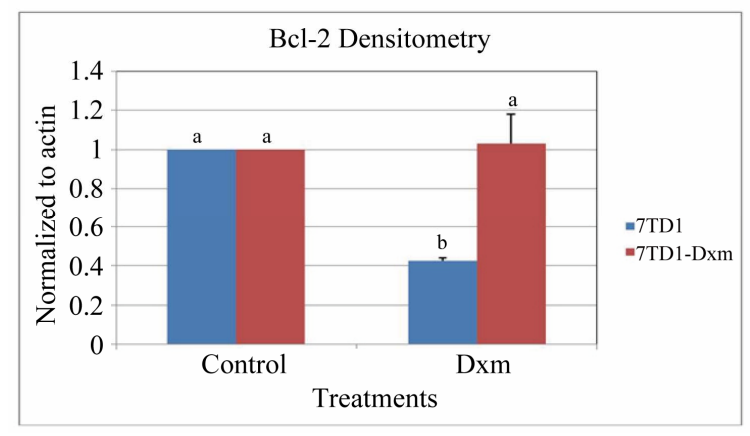

(c)

Figure 3. (a) Dexamethasone-resistant 7TD1 cells were resistant to reduction of protein levels of Bcl-2. 7TD1 cells were treated with/without interleukin-6 $(4 \mathrm{ng} / \mathrm{ml})$ and 7TD1Dxm cells without IL6 and both the cell lines treated with $50 \mu \mathrm{M}$ AG490 or $85 \mu \mathrm{M}$ dexamethasone and incubated for $48 \mathrm{hrs}$ at $37^{\circ} \mathrm{C}$. After incubation, cells were collected and lysates prepared and subjected to Western blot analysis for detection of $\mathrm{Bcl}-2$ protein levels. The experiment was repeated three times; (b) Protein levels of $B c l-X_{L}$ were unaffected by dexamethasone treatment in 7TD1 cells. 7TD1 cells were treated with/without interleukin-6 $(4 \mathrm{ng} / \mathrm{ml})$ and 7TD1-Dxm cells without IL6 and both the cell lines treated with $50 \mu M$ AG490 and $85 \mu M$ dexamethasone and incubated for $48 \mathrm{hrs}$ at $37^{\circ} \mathrm{C}$. After incubation, cells were collected and lysates prepared and subjected to Western blot analysis for detection of $\mathrm{Bcl}-\mathrm{X}_{\mathrm{L}}$ protein levels. The experiment was repeated three times; (c) Densitometry analysis of results from Western Blot analysis of Bcl-2 protein. Average pixel intensity of each band was obtained by using UnScanIt software. The values were then normalized with $\beta$ actin, positive control and percent control calculated for each value. Values represent mean \pm S.D. of duplicate values from triplicate samples of pixel intensities as obtained from densitometric analysis and normalized to actin.

cells were completely resistant to reduction of Bcl-2 protein upon treatment with Dxm. This effect of reducing
Bcl-2 appears to be specific as Bcl- $\mathrm{X}_{\mathrm{L}}$ was unaffected by Dxm treatment (Figure 3(b)). This observation led us to propose a role for dexamethasone in differential regulation of the anti-apoptotic proteins downstream to JAK/ STAT3 signaling pathway in the process of acquisition of the Dxm-resistant phenotype and confirmed our assumption about the involvement of mitochondrial pathway of apoptosis induction in the development of resistance in these cells. Parent 7TD1 cells were treated with IL6 at $4 \mathrm{ng} / \mathrm{ml}$ which was used as a negative control. The densitometric analysis of the results obtained from Bcl-2 western blot analysis (Figure 3(c)) shows that while in the parent 7TD1 cells the protein levels of Bcl-2 significantly decreased upon treatment with dexamethasone alone, in 7TD1-Dxm cells Bcl-2 protein levels were resistant to reduction by dexamethasone.

\subsection{Dexamethasone-Resistant 7TD1 Cells Were Resistant to Cytochrome C Release upon Treatment with Dexamethasone}

We next examined the effect of dexamethasone on cytochrome c release from mitochondria into the cytoplasm which is a downstream event that occurs after reduction of Bcl-2 protein. Histogram analysis of the data obtained from flow cytometric analysis suggested while there was a shift in the peak observed in parent 7TD1 cells treated with dexamethasone alone at $85 \mu \mathrm{M}$ when compared to control, suggesting a release in the cytochrome $\mathrm{c}$ into the cytoplasm, no shift was observed in 7TD1-Dxm cells treated with dexamethasone alone as compared to control (Figures 4(a) and (b)). Figures 4(c) shows that treatment with HA-14-1 at $20 \mu \mathrm{M}$ alone and in combination with $85 \mu \mathrm{M}$ dexamethasone induced significant release of cytochrome c into the cytoplasm (up to $70 \%$ labeled cells were observed) indicating the role of Bcl-2 in regulating the release of cytochrome $\mathrm{c}$ from the inter-membranal space of mitochondria. Upon treatment with dexamethasone alone, 7TD1-Dxm cells showed resistance to release of cytochrome $\mathrm{c}$ while the parent 7TD1 cells showed a significant labeling of the cells ( $40 \%$ labeled cells observed compared to control) suggesting release of cytochrome $\mathrm{c}$ into the cytoplasm. This result is consistent with the effect of Dxm treatment on Bcl-2 protein expression and suggests a role for mitochondria in the development of resistance by these cells.

\subsection{Mitochondrial Membrane Potential Disruption Was Not Observed in Both Parent 7TD1 and Dxm-Resistant 7TD1 Cells}

Since cytochrome c release was not observed in 7TD1Dxm cells upon dexamethasone treatment, we further determined the MMP as its disruption can be a prior step for release of cytochrome c. We treated both cell lines 


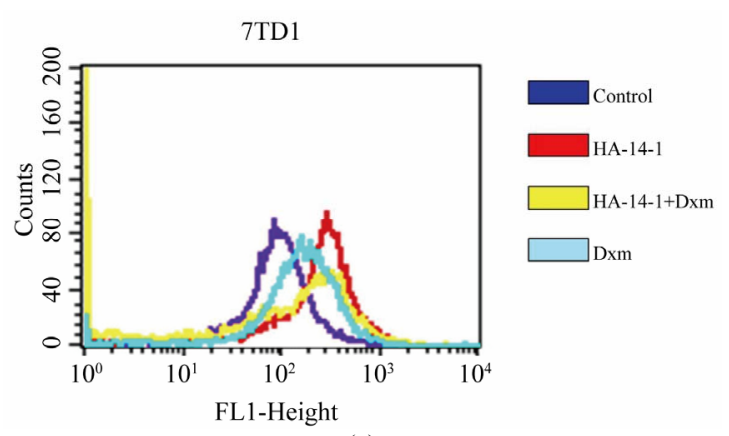

(a)

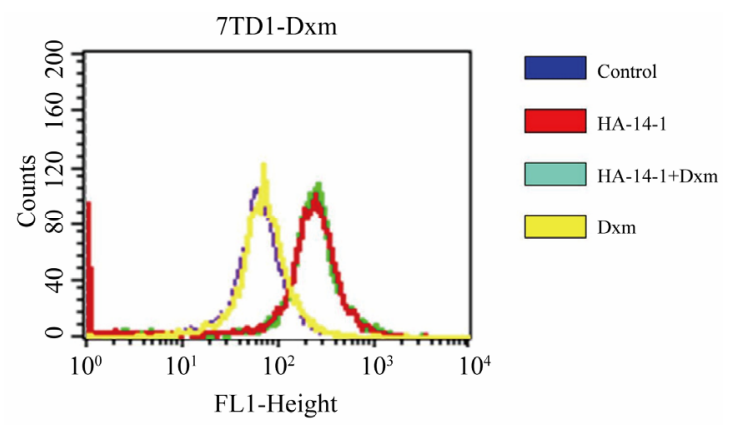

(b)

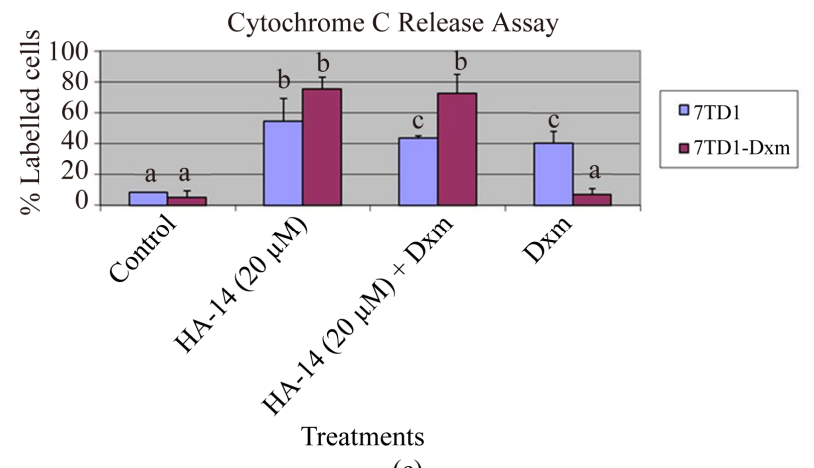

(c)

Figure 4. Histogram analysis of flow cytometric data for release of cytochrome $c$ into the cytoplasm. (a) Parent 7TD1 cells where Purple peak represents control, Red represents HA-14-1 treatment alone at $20 \mu \mathrm{M}$ concentration, Yellow represents treatment with $\mathrm{HA}-14-1$ at $20 \mu \mathrm{M}$ in the presence of dexamethasone at $85 \mu \mathrm{M}$ concentration, and Blue represents treatment with dexamethasone alone at $85 \mu \mathrm{M}$ concentration; (b) 7TD1-Dxm cells where Purple peak represents control, Red represents HA-14-1 treatment alone at $20 \mu \mathrm{M}$ concentration, Green represents treatment with HA-14-1 at $20 \mu \mathrm{M}$ in the presence of dexamethasone at 85 $\mu \mathrm{M}$ concentration, and Yellow represents treatment with dexamethasone alone at $85 \mu \mathrm{M}$ concentration; (c) Cytochrome $c$ release from the mitochondria was not observed in the 7TD1-Dxm cells upon treatment with dexamethasone. Both 7TD1 and 7TD1-Dxm cells were treated with either dexamethasone $(85 \mu \mathrm{M})$ alone or HA-14-1 at $20 \mu \mathrm{M}$ alone or HA-14-1 in combination with dexamethasone and incubated for $24 \mathrm{hrs}$ at $37^{\circ} \mathrm{C}$. After $24 \mathrm{hrs}$ the cells were subjected to a cytochrome $c$ release assay following the manufacturer's protocol and analyzed by flow cytometer (Becton Dickinson, San Jose, CA). Values represent the average percent apoptotic cells \pm S.D. for triplicate assays. with IL6 (4 ng/ml), AG490 at $50 \mu \mathrm{M}, \mathrm{HA}-14-1$ at $20 \mu \mathrm{M}$, alone and in combination with dexamethasone $(85 \mu \mathrm{M})$ or with dexamethasone alone at $85 \mu \mathrm{M}$ for a period of 24 hrs. Figure 5 shows that both parent 7TD1 cells and 7TD1-Dxm cells were resistant to inhibition of MMP suggesting that MMP disruption was not responsible for releasing cytochrome c. Thus, other mechanism(s) are likely involved. Similar results were obtained even when the incubation period was extended to 48 or $72 \mathrm{hrs}$.

\section{Discussion}

Several studies have shown that changes in expression of Bcl-2 family proteins may lead to chemotherapeutic resistance and vigorous growth of myeloma cells in the bone marrow microenvironment (BMM) [12,14,16-18]. Our previous studies have indicated a role of constitutively activated STAT3 in controlling induction of apoptosis in 7TD1-Dxm cells [22]. In the current study, we focused on investigating the role of downstream targets of activated STAT3 in the development of resistance to dexamethasone in 7TD1-Dxm cells. We found that treatment with HA-14-1 alone, a Bcl-2 specific inhibitor significantly inhibited proliferation of 7TD1-Dxm cells at $20 \mu \mathrm{M}$ itself and also induced apoptosis in both parent 7TD1 and 7TD1-Dxm cells (Figures 1 and 2). The sensitivity of the 7TD1-Dxm cells was not altered when treated in combination with dexamethasone.

Over-expression of the anti-apoptotic proteins such as Bcl-2 has been shown to play a role in the survival of MM cells and development of drug resistance [12,15]. Gauthier et al. have investigated the role of $\mathrm{Bcl}-\mathrm{X}_{\mathrm{L}}$ in the control of apoptosis in murine myeloma cells [25]. Quintinella-Martinez et al. have noted the relationship between IL6, STAT3 activation and Bcl-2, Bcl-X $\mathrm{L}_{\mathrm{L}}$ expression and their role in promoting proliferation of myeloma cells [21].

Therefore, we focused our current investigations on the regulation of $\mathrm{Bcl}-2$ protein expression. Our results showed that 7TD1-Dxm cells were resistant to reduction of $\mathrm{Bcl}-2$ protein upon treatment with dexamethasone alone, unlike the parent 7TD1 cells which showed significant reduction of protein levels of Bcl-2 when treated with Dxm (Figure 3(a)). No observable changes were detected in Bcl- $\mathrm{X}_{\mathrm{L}}$ protein levels in both cell lines (Figure 3(b)). Detection of Mcl-1 (Myeloid Cell Leukemia factor-1), an anti-apoptotic protein known to play a role in the survival of MM cells [15], suggested that it was constitutively expressed in both parent 7TD1 and 7TD1Dxm cells, both at the transcriptional- and translationallevel (data not shown). When combined, our results suggested a further investigation of the role of mitochondria in development of resistance to dexamethasone by 7TD1Dxm cells. It is known that Bcl-2 protein controls apoptosis induction and/or inhibition by regulation at the level 


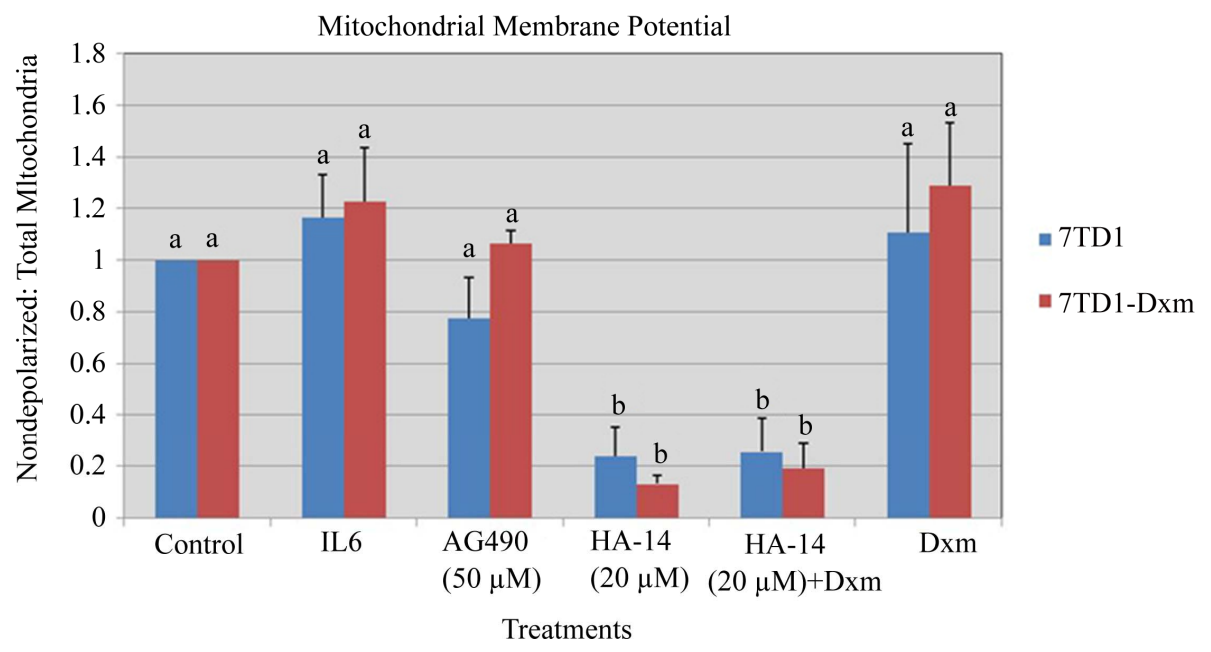

Figure 5. MMP disruption was not observed in both parent 7TD1 and 7TD1-Dxm cells. Both 7TD1 and 7TD1-Dxm cells were treated with IL6 at $4 \mathrm{ng} / \mathrm{ml}$ or AG490 at $50 \mu \mathrm{M}$ or HA-14-1 alone at $20 \mu \mathrm{M}$ and in combination with dexamethasone or with dexamethasone alone in a time-dependent manner. Cells were analyzed using flow cytometer after 24 hrs. After each timepoint cells were collected, Mitotracker red and Mitotracker green dyes were added for a final concentration of $250 \mathrm{nM}$ and $150 \mathrm{nM}$, respectively. They were incubated at $37^{\circ} \mathrm{C}$ for $30 \mathrm{~min}$ and washed twice with ice cold $1 \times \mathrm{PBS}$ at $200 \times \mathrm{g}$ for $6 \mathrm{~min}$., and resuspended in $400 \mu \mathrm{l}$ of $1 \times$ PBS and analyzed by flow cytometer (Becton Dickinson, San Jose, CA). Values represent the ratio of average of mean fluorescence values from non-depolarized to total mitochondria, \pm S.D. for triplicate assays, normalized to control.

of mitochondria. Disruption of mitochondrial membrane potential and release of cytochrome c from the mitochondrial inter-membranal space are pre-requisite steps to induce the sequential events leading to cell death. Our results indicated that 7TD1-Dxm cells were resistant to release of cytochrome $\mathrm{c}$ from the mitochondria while the parent 7TD1 cells showed a significant increase in the percent labeled cells indicating the release of cytochrome $\mathrm{c}$ upon treatment with dexamethasone (Figure 4).

Since cytochrome c release is known to be accompanied with a change in the mitochondrial membrane permeability $[12,26,27]$, we next investigated the regulation of MMP in these cells. We found that MMP was not disrupted during treatment with dexamethasone, in either parent 7TD1 or 7TD1-Dxm cells (Figures 5). This finding indicates that there may be ways for cytochrome $\mathrm{c}$ release other than the disruption of MMP leading to formation of membrane transition pores (MPT). Indeed, Von Ahsen et al. have suggested there were ways other than disruption of MMP for the release of cytochrome $\mathrm{c}$ [27]. A number of studies have also suggested that disruption of the MMP was not required for cytochrome c release [28-32]. Thus our results are consistent with the possibility that mitochondria can be induced to release their cytochrome $\mathrm{c}$ without disruption of their membrane potential.

Several studies have focused on utilizing inhibitors of $\mathrm{Bcl}-2 / \mathrm{Bcl}-\mathrm{X}_{\mathrm{L}}$ to induce apoptosis in $\mathrm{MM}$ cells [33-39]. Previously, Rosen et al. have established three different MM cell lines; MM.1S (sensitive to treatment with glu- cocorticoids), MM. $1 R_{E}$ (resistant to treatment with glucocorticoids), MM. $1 R_{L}$ (resistant to treatment with glucocorticoids) in order to study the progression of MM and the mechanisms responsible for resistance to glucocorticoids including dexamethasone [40]. A study conducted by Rosen et al., using the MM cell lines showed that apoptosis induction by glucocorticoids like dexamethasone was mediated through glucocorticoid-induced leucine zipper (GILZ) [41]. Furthermore, Rosen et al. found that PI3K/AKT signaling pathway played a role in the regulation of GILZ and indicated that the use of glucocorticoid in combination with PI3K inhibitor may be useful in treating clinical resistance of multiple myeloma [41]. Our present findings demonstrate that resistance to dexamethasone in 7TD1 cells is accompanied by the inhibition of cytochrome $\mathrm{c}$ release from the mitochondria upon treatment with Dxm. There may be, however, other mechanisms responsible for the development of Dxmresistance. Nevertheless, our finding is novel in that we have established a Dxm-resistant phenotype of 7TD1 cells in the absence of IL6 and they are also IL6-independent for growth. Employing this phenotype we have elucidated a potential mechanism responsible for development of resistance to dexamethasone. Clearly, this is an important area that deserves further investigation.

\section{Acknowledgements}

This study was supported by NIH Grant P20RR16454 from the INBRE program of the National Center for Research Resources. 


\section{REFERENCES}

[1] A. G. Moses, J. Maingay, K. Sangster, K. C. Fearon and J. A. Ross, "Proinflammatory Cytokine Release by Peripheral Blood Mononuclear Cells from Patients with Advanced Pancreatic Cancer: Relationship to Acute Phase Response and Survival," Oncology Reports, Vol. 21, No. 4, 2009, pp. 1091-1095.

[2] Y. Y. Li, L. L. Hsieh, R. P. Tang, S. K. Liao and K. Y. Yeh, "Interleukin-6 (IL-6) Released by Macrophages Induces IL-6 Secretion in the Human Colon Cancer HT-29 Cell Line," Human Immunology, Vol. 70, No. 3, 2009, pp. 151-158. doi:10.1016/j.humimm.2009.01.004

[3] M. Colombatti, S. Grasso, A. Porzia, G. Fracasso, M. Y. Scupoli, S. Cingarlini, O. Poffe, H. Y. Naim, M. Heine, G. Tridente, F. Mainiero and D. Ramarli, "The Prostate Specific Membrane Antigen Regulates the Expression of IL-6 and CCL5 in Prostate Tumour Cells by Activating the MAPK Pathways," PLoS One, Vol. 4, No. 2, 2009, p. e4608. doi:10.1371/journal.pone.0004608

[4] S. Feng, Q. Tang, M. Sun, J. Y. Chun, C. P. Evans and A. C. Gao, "Interleukin-6 Increases Prostate Cancer Cells Resistance to Bicalutamide via TIF2," Molecular Cancer Therapy, Vol. 8, No. 3, 2009, pp. 665-671. doi:10.1158/1535-7163.MCT-08-0823

[5] M. Hallek, L. Bergsagel and K. C. Anderson, "Multiple Myeloma: Increasing Evidence for a Multistep Transformation Process," Blood, Vol. 91, No. 1, 1998, pp. 321.

[6] R. A. Kyle and S. V. Rajkumar, "Multiple Myeloma," Blood, Vol. 111, No. 5, 2008, pp. 2962-2972. doi:10.1182/blood-2007-10-078022

[7] K. C. Anderson, "Moving Disease Biology from the Lab to the Clinic," Cancer, Vol. 97, No. 3, 2003, pp. 796-801. doi:10.1002/cncr.11137

[8] D. Chauhan, P. Pandey, T. Hideshima, S. Treon, N. Raje, F. E. Davies, Y. Shima, Y. T. Tai, S. Rosen, S. Avraham, S. Kharbanda and K. C. Anderson, "SHP2 Mediates the Protective Effect of Interleukin-6 against DexamethasoneInduced Apoptosis in Multiple Myeloma Cells," Journal of Biological Chemistry, Vol. 275, 2000, pp. 27845-27850.

[9] D. Chauhan and K. C. Anderson, "Apoptosis in Multiple Myeloma: Therapeutic Implications," Apoptosis, Vol. 6, No. 1-2, 2001, pp. 47-55. doi:10.1023/A:1009620027205

[10] T. Hideshima and K. C. Anderson, "Molecular Mechanisms of Novel Therapeutic Approaches for Multiple Myeloma," Nature Reviews, Cancer, Vol. 2, No. 12, 2002, pp. 927-937. doi:10.1038/nrc952

[11] D. Chauhan and K. C. Anderson, "Mechanisms of Cell Death and Survival in Multiple Myeloma (MM): Therapeutic Implications," Apoptosis, Vol. 8, No. 4, 2003, pp. 337-343. doi:10.1023/A:1024164700094

[12] M. Oancea, A. Mani, M. A. Hussein and A. Almasan, "Apoptosis of Multiple Myeloma," International Journal of Hematology, Vol. 80, No. 3, 2004, pp. 224-231. doi:10.1532/IJH97.04107

[13] Q. Chen, B. Gong, A. S. Mahmoud-Ahmed, A. Zhou, E. D. His, M. Hussein and A. Almasan, "Apo2L/TRAIL and Bcl-2-Related Proteins Regulate Type I Interferon-In- duced Apoptosis in Multiple Myeloma," Blood, Vol. 98, No. 7, 2001, pp. 2183-2192.

doi:10.1182/blood.V98.7.2183

[14] Q. Chen, S. Ray, M. A. Hussein, G. Srkalovic and A. Almasan, "Role of Apo2L/TRAIL and Bcl-2 Family Proteins in Apoptosis of Multiple Myeloma," Leukemia and Lymphoma, Vol. 44, No. 7, 2003, pp. 1209-1214. doi:10.1080/1042819031000068052

[15] B. Zhang, I. Gojo and R. G. Fenton, "Myeloid Cell Factor-1 Is a Critical Survival Factor for Multiple Myeloma," Blood, Vol. 99, No. 5, 2002, pp. 1885-1893. doi:10.1182/blood.V99.6.1885

[16] Y. Tu, S. Renner, F. Xu, A. Fleishman, J. Taylor, J. Weisz, R. Vescio, M. Rettig, J. Berenson, S. Krajewski, J. C. Reed and A. Lichtenstein, "BCL-X Expression in Multiple Myeloma: Possible Indicator of Chemoresistance," Cancer Research, Vol. 58, 1998, pp. 256-262.

[17] M. Linden, N. Kirchhof, C. Carlson and B. Van Ness, "Targeted Overexpression of BCL-XL in B-Lymphoid Cells Results in Lymphoproliferative Disease and Plasma Cell Malignancies," Blood, Vol. 103, No. 7, 2004, pp. 2779-2786. doi:10.1182/blood-2003-10-3399

[18] R. Catlett-Falcone, T. H. Landowski, M. M. Oshiro, J. Turkson, A. Levitzki, R. Savino, G. Ciliberto, L. Moscinski, J. L. Fernandez-Luna, G. Nunez, W. S. Dalton and R. Jove, "Constitutive Activation of STAT3 Signaling Confers Resistance to Apoptosis in Human U266 Myeloma Cells," Immunity, Vol. 10, No. 1, 1999, pp. 105-115. doi:10.1016/S1074-7613(00)80011-4

[19] A. K. Pathak, M. Bhutani, A. S. Nair, K. S. Ahn, A. Chakraborty, H. Kadara, S. Guha, G. Sethi and B. B. Aggarwal, "Urosilic Acid Inhibits STAT3 Activation Pathway Leading to Suppression of Proliferation and Chemosensitization of Human Multiple Myeloma Cells," Molecular Cancer Research, Vol. 5, 2007, pp. 943-955. doi:10.1158/1541-7786.MCR-06-0348

[20] L. H. Wang, X. Y. Yang, X. Zhang, J. Huang, J. Hou, J. Li, H. Xiong, K. Mihalic, H. Zhu, W. Xiao and W. L. Farrar, "Transcriptional Inactivation of STAT3 by PPAR $\gamma$ Suppresses IL-6-Responsive Multiple Myeloma Cells," Immunity, Vol. 20, No. 2, 2004, pp. 205-218. doi:10.1016/S1074-7613(04)00030-5

[21] L. Quintanilla-Martinez, M. Kremer, K. Specht, J. Calzada-Wack, M. Nathrath, R. Schaich, H. Hofler and F. Fend, "Analysis of Signal Transducer and Activator of Transcription 3 (STAT3) Pathway in Multiple Myeloma," American Journal of Pathology, Vol. 162, No. 5, 2003, pp. 1449-1461. doi:10.1016/S0002-9440(10)64278-2

[22] K. J. Gangavarapu, J. L. Olbertz, A. Bhushan, J. C. K. Lai and C. K. Daniels, "Apoptotic Resistance Exhibited by Dexamethasone-Resistant Murine 7TD1 Cells Is Controlled Independently of Interleukin-6 Triggered Signaling," Apoptosis, Vol. 13, No. 11, 2008, pp. 1394-1400. doi:10.1007/s10495-008-0265-y

[23] B. Irvin, C. Hanson, L. Smith and C. K. Daniels, "Cyclic Amp-IL6-Signaling Cross Talk: Comodulation of Proliferation and Apoptosis in the 7TD1 B Cell Hybridoma," Experimental Cell Research, Vol. 265, No. 1, 2001, pp. 73-79. doi:10.1006/excr.2001.5157 
[24] T. Mosmann, "Rapid Colorimetric Assay for Cellular Growth and Survival: Application to Proliferation and Cytotoxicity Assays," Journal of Immunological Methods, Vol. 65, No. 1-2, 1983, pp. 55-63. doi:10.1016/0022-1759(83)90303-4

[25] E. R. Gauthier, L. Piche, G. Lemieux and R. Lemieux, "Role of bcl-X1 in the Control of Apoptosis in Murine Myeloma Cells," Cancer Research, Vol. 56, No. 6, 1996, pp. 1451-1456.

[26] R. Khosravi-Far and M. D. Esposti, "Death Receptor Signals to Mitochondria," Cancer Biology \& Therapy, Vol. 3, No. 11, 2004, pp. 1051-1057. doi:10.4161/cbt.3.11.1173

[27] O. Von Ahsen, N. J. Waterhouse, T. Kuwana, D. D. Newmeyer and D. R. Green, "The 'Harmless' Release of Cytochrome C," Cell Death and Differentiation, Vol. 7, No. 12, 2000, pp. 1192-1199. doi:10.1038/sj.cdd.4400782

[28] S.-M. Chiu and N. L. Oleinick, "Dissociation of Mitochondrial Depolarization form Cytochrome C Release during Apoptosis Induced by Photodynamic Therapy," British Journal of Cancer, Vol. 84, 2001, pp. 1099-1106. doi:10.1054/bjoc.2000.1714

[29] D. M. Finucane, N. J. Waterhouse, G. P. Amarante-Mendes, T. G. Cotter and D. R. Green, "Collapse of the Inner Mitochondrial Transition Potential Is Not Required for Apoptosis in HL60 Cells," Experimental Cell Research, Vol. 251, No. 1, 1999, pp. 166-174. doi:10.1006/excr.1999.4527

[30] D. M. Finucane, E. BossyWetzel, N. J. Waterhouse, T. G. Cotter and D. R. Green, "Bax-Induced Caspase Activation and Apoptosis via Cytochrome C Release from Mitochondria Is Inhibitable by Bcl-xL," Journal of Biological Chemistry, Vol. 274, 1999, pp. 2225-2233. doi:10.1074/jbc.274.4.2225

[31] R. Eskes, B. Antonsson, A. Osen-Sand, S. Montessuit, C. Richter, R. Sadoul, G. Mazzei, A. Nichols and J.-C. Martinou, "Bax-Induced Cytochrome C Release form Mitochondria Is Independent of the Permeability Transition Pore but Highly Dependent on Mg2+ Ions," Journal of Cell Biology, Vol. 143, No. 1, 1998, pp. 217-224. doi:10.1083/jcb.143.1.217

[32] R. M. Kluck, E. Bossy-Wetzel, D. R. Green and D. D. Newmeyer, "The Release of Cytochrome C from Mitochondria: A Primary Site for Bcl-2 Regulation of Apoptosis," Science, Vol. 275. No. 5303, 1997, pp. 1132-1136. doi:10.1126/science.275.5303.1132

[33] A. Muto, M. Hori, Y. Sasaki, A. Saitoh, I. Yasuda, T. Maekawa, T. Uchida, K. Asakura, T. Nakazato, T. Kaneda, M. Kizaki, Y. Ikeda and T. Yoshida, "Emodin Has a Cytotoxic Effect against Human Multiple Myeloma as a
Janus-Activated Kinase 2 Inhibtor," Molecular Cancer Therapy, Vol. 6, 2007, pp. 987-994.

doi:10.1158/1535-7163.MCT-06-0605

[34] X. Y. Pei, Y. Dai and S. Grant, "The Proteasome Inhibitor Bortezomib Promotes Mitochondrial Injury and Apoptosis Induced by the Small Molecule Bcl-2 Inhibitor HA14-1 in Multiple Myeloma Cells," Leukemia, Vol. 17, 2003, pp. 2036-2045. doi:10.1038/sj.leu.2403109

[35] S. Trudel, A. K. Stewart, Z. Li, Y. Shu, S. B. Liang, Y. Trieu, D. Reece, J. Paterson, D. Wang and X. Y. Wen, "The Bcl-2 Family Protein Inhibitor, ABT-737, Has Substantial Antimyeloma Activity and Shows Synergistic Effect with Dexamethasone and Melphalan," Clinical Cancer Research, Vol. 13, 2007, pp. 621-629. doi:10.1158/1078-0432.CCR-06-1526

[36] M. Bhutani, A. K. Pathak, A. S. Nair, A. B. Kunnumakkara, S. Guha, G. Sethi and B. B. Aggarwal, "Capsaicin Is a Novel Blocker of Constitutive and Interleukin-6-Inducible STAT3 Activation," Clinical Cancer Research, Vol. 13, 2007, pp. 3024-3032. doi:10.1158/1078-0432.CCR-06-2575

[37] J. Lotem and L. Sachs, "Regulation of bcl-2, bcl-XL and Bax in the Control of Apoptosis by Haemopoeitic Cytokines and Dexamethasone," Cell Growth \& Differentiation, Vol. 6, 1995, pp. 647-653.

[38] M. M. K. Schwarze and R. G. Hawley, "Prevention of Myeloma Cell Apoptosis by Ectopic bcl-2 Expression or Interleukin 6-Mediated Up-Regulation of bcl-xL," Cancer Research, Vol. 55, No. 11, 1995, pp. 2262-2265.

[39] M. Yang, J. Huang, H. Z. Pan and J. Jin, "Triptolide Over-Comes Dexamethasone Resistance and Enhanced PS-341-Induced Apoptosis via PI3k/Akt/NF-kappaB Pathways in Human Multiple Myeloma Cells," International Journal of Molecular Medicine, Vol. 22, No. 4, 2008, pp. 489-496.

[40] S. Greenstein, N. L. Krett, Y. Kurosawa, C. Ma, D. Chauhan, T. Hideshima, K. C. Anderson and S. T. Rosen, "Characterization of the MM.1 Human Multiple Myeloma (MM) Cell Lines: A Model System to Elucidate the Charactersistics, Behavior, and Signaling of Steroid-Sensitive and -Resistant MM Cells," Experimental Hematology, Vol. 31, 2003, pp. 271-282. doi:10.1016/S0301-472X(03)00023-7

[41] K. D. Grugan, C. Ma, S. Singhal, N. L. Krett and S. T. Rosen, "Dual Regulation of Glucocorticoid-Induced Leucine Zipper (GILZ) by the Glucocorticoid Receptor and the PI3Kinase/AKT Pathways in Multiple Myeloma," The Journal of Steroid Biochemistry and Molecular Biology, Vol. 110, No. 3-5, 2008, pp. 244-254. doi:10.1016/j.jsbmb.2007.11.003 